Marquette University

e-Publications@Marquette

$1-1-2007$

\title{
Globalization, Expectations Model of Economic Nationalism, and Consumer Behavior
}

Syed H. Akhter

Marquette University, syed.akhter@marquette.edu

Accepted version. Journal of Consumer Marketing, Vol. 24, No. 3 (2007): 142-150. DOI. (C) 2007 Emerald. Used with permission. 


\title{
Globalization, expectations model of economic nationalism, and consumer behavior
}

\author{
Syed H. Akhter \\ Department of Marketing, Marquette University \\ Milwaukee, WI
}

\begin{abstract}
:
Purpose - The goals of the paper are to propose, measure, and empirically test the expectations model of economic nationalism. The model posits that economic nationalism is reflected in people's expectations of their government, domestic firms, and the general public, in terms of restricting the activities of foreign firms.
\end{abstract}

Design/methodology/approach - A confirmatory factor analysis is conducted to test the model, using the LISREL procedure.

Findings - Results show acceptable fit for the proposed model. Reliability of each of the three dimensions of economic nationalism is in the acceptable range. A nomological validity test showed that economic nationalism is related to other constructs not included in the model.

Research limitations/implications - A limitation of the model is that it is based on a single sample. Future studies can test the generalizability of model with samples from different countries.

Practical implications - The implication of the study is that increasing globalization might lead to an increase in economic nationalism. Business executives, therefore, need to focus not only on the benefits that they will derive from entering a country, but also the benefits they will deliver to the domestic economy by entering the country.

Originality/value - The paper presents an expectations model of economic nationalism. The model is based on the premise that people's expectations of

Journal of Consumer Marketing, Vol 24, No. 9 (2007): pg. 142-150. DOI. This article is (C) Emerald and permission has been granted for this version to appear in e-Publications@Marquette. Emerald does not grant permission for this article to be further copied/distributed or hosted elsewhere without the express permission from Emerald. 
NOT THE PUBLISHED VERSION; this is the author's final, peer-reviewed manuscript. The published version may be accessed by following the link in the citation at the bottom of the page.

their government, domestic businesses, and the general public in terms of their role in restricting the activities of foreign firms are reflective of economic nationalism. The more people expect of these three players the more economically nationalistic they will be. The value of the paper is to researchers in international business and global marketing and to business executives involved in managing global operations.

Keywords: Globalization, Economics, Consumer behaviour, Marketing strategy

\section{An executive summary for managers and executive readers can be found at the end of this article.}

There is a growing realization among academics and executives that the rising pace of globalization will continue to generate a backlash across countries with calls for greater restrictions on global trade and investment. Globalization is now a controversial development with different groups selecting different issues to criticize it. Among other things, globalization is associated with exploitation of workers and the environment and the widening inequalities and disparities in the world (Segal-Horn, 2002). Globalization is also said to have increased unemployment (Agiomirgiankis and Zervoyinanni, 2001) and undermined social cohesion (Greider, 1997) and sense of community and urban power structure (Knox, 1997; Mele, 1996).

Complaints against globalization have been gaining momentum in recent years so much so that whenever the World Trade Organization (WTO) and International Monetary Fund (IMF) hold their meetings, people come out on the streets to protest against them and their global agenda. Joining these protestors are also opinion leaders, politicians, and commentators who voice their concerns about the negative consequences of the increasing flow of products, services, and capital across countries. Invoking the idea of equity and distributive justice, these groups contend that globalization, left to the vagaries of market forces, will adversely affect different groups of people by lowering wages, raising unemployment, and reducing domestic firms' competitiveness.

Thus, the idea of managing the activities of multinational corporations finds a receptive audience not only in less developed and Journal of Consumer Marketing, Vol 24, No. 9 (2007): pg. 142-150. DOI. This article is (c) Emerald and permission has been granted for this version to appear in e-Publications@Marquette. Emerald does not grant permission for this article to be further copied/distributed or hosted elsewhere without the express permission from Emerald. 
developing economies, but also in the more advanced economies. In India, for example, the entry of McDonald's and Kentucky Fried Chicken was seen by many as a threat to the market positions of domestic retailers. Prominent Indians argued for greater protection of domestic businesses from these multinationals. In Brazil, increasing economic nationalism has given rise to protectionism and a lack of openness to trade and investment (The Economist, 2000). And in the USA, in the run-up to the 2004 presidential election, democratic candidates in the primaries took up the issue of the adverse consequences of growth in international trade and outsourcing on US workers and firms, making economic nationalism a centerpiece of their campaigns (Weisman, 2004).

Although economic nationalism is now seen as a force that can potentially slow down the march of globalization, if not necessarily derail it, the concept itself is contentious and subject to varied interpretations. Burnell (1986), for example, noted that the concept of economic nationalism has not been explored adequately. Furthermore, Baughn and Yaprak Journal of Consumer Marketing (1996, p. 760) note that the conceptualization of economic nationalism does not go beyond explicating the "economic practices and policy measures that historically have come to be characterized as nationalist." Furthermore, a review of the literature indicates that the term economic nationalism is often confused with other related but conceptually different terms such as nationalism, patriotism, ethnocentrism, and consumer ethnocentrism, thus compounding the ontological and epistemological problems.

Given this theoretical situation and the continuing strategic significance of economic nationalism, we propose that that a rigorous treatment of the concept would not only add to the body of literature but also enhance our understanding of the phenomenon. To fill the gap in the literature, this paper proposes and tests the expectations model of economic nationalism. To achieve this goal, we do the following: first, explain the bases for economic nationalism, second, differentiate economic nationalism from related but conceptually different concepts, third, present the expectations model of economic nationalism, fourth, suggest empirical indicators to measure the concept and conduct a confirmatory factor analysis to judge the fit of the proposed expectations model, fifth, conduct a nomological validity test, and, 
sixth, conclude with a discussion of theoretical and strategic implications.

\section{Bases for economic nationalism}

Economic nationalism has been and will continue to be a contentious issue. While it is surely not a recent phenomenon, its manifestations in today's global economy have been frequent and portentous. Consumers boycott foreign products, purchasing agents deny access to foreign suppliers, executives refuse to sell their business to foreign firms, and governments continue to erect international trade and investment barriers. Recently, the European Commission President, Jose Manuel Barroso, warned against the rising tide of economic nationalism in the European Union. His comments were in the wake of France's action in forcing a merger between Suez SA and Gaz de France SA to prevent a takeover of Suez by an Italian firm Enel SpA, and Spain's action in blocking a bid by the German energy giant E.ON AG for the electricity company Endesa (World Peace Herald, 2006).

As global business activities are becoming more integrated, the rise in economic nationalism can prove highly disruptive to multinationals' value chain and marketing activities. Among executives, there is thus a lingering fear that the actions of others that are beyond their control can seriously disrupt the conduct of regular business and marketing activities. These executives recognize the importance of unhindered access to foreign resources and markets. At the same time they also realize that economic nationalism can not only prevent access to these resources and markets but also adversely affect their operations in these countries. In the USA, for example, the recent takeover bid of Unocal by CNOOC of China was thwarted because of the strong opposition in the Congress. Weinstein, in responding to this and other developments points to the growing influence of "economic nationalism" in the USA (Power and Interest News Report, 2006).

Motivations for economic nationalism can be traced to political, economic, and security factors. The political basis for economic nationalism finds its justification in the conduct of many foreign firms in different host countries. The East India Company of Britain, for example, played a dubious role in turning India into a colony of the Journal of Consumer Marketing, Vol 24, No. 9 (2007): pg. 142-150. DOI. This article is (c) Emerald and permission has been granted for this version to appear in e-Publications@Marquette. Emerald does not grant permission for this article to be further copied/distributed or hosted elsewhere without the express permission from Emerald. 
British Empire. The ITT of the USA, for example, was instrumental in toppling the democratically elected government of Allende in Chile. More recently, several firms including OMG, Bayer, and Cabot Corp. have been cited in a UN report on the illegal exploitation of natural resources in the Democratic Republic of Congo (Westervelt, 2002). The legacies of these firms still reverberate in people's psyche. Many South Koreans, for example, continue to oppose foreign investors from setting up domestic factories and offices in South Korea (Lee, 1998) and view foreign ownership of domestic businesses as an expression of colonial control (Hoon and Lee, 1998).

The economic basis for economic nationalism rests on the desire to protect domestic business interests. When foreign firms come to a country with better financial resources and marketing know how, they are perceived as a threat to domestic business. Economic nationalism thus becomes a response to the fear of losing control of domestic businesses to foreign firms and the concomitant development of an uncertain future (Miller, 1990; Reich, 1991). The operant belief is that increasing international trade may jeopardize the survival and growth of some domestic firms and vitiate the pursuit of domestic economic well being (Han, 1988). Economic nationalism thus not only encourages behaviors in support of domestic industries, firms, and products, but also magnifies the distinction between domestic and foreign firms. In South Korea, for example, during the recent financial crisis, store fronts carried signs proclaiming that only "100\% Korean" goods were sold inside (Slater, 1998).

National security has historically been a persuasive argument for economic nationalism. Security concerns arise from the beliefs and fears that people have about foreign firms. The belief is that homebased firms are more committed to achieving domestic goals and aspirations than foreign-based firms. This belief coupled with the fear of not knowing what foreign firms will end up doing strengthens people's commitment to protect domestic economy from the influences of foreign firms. Recently, when Dubai Port Worlds, a Dubai-based firm, took control to manage terminal operations at six US ports, Congressional outcry and public concerns over security of the ports forced the company to divest itself of these holdings. And, in France, the government recently passed a law that puts several strategic industries off limits to foreign takeovers (Lander and Meller, 2006). 
As the discussions above illustrate, economic nationalism remain a force in today's global economy in restricting the activities of business corporations, large and small, in different parts of the world. The agenda of economic nationalism will continue to move forward because of societal concerns about the role of foreign firms. These concerns remain appealing and persuasive, as they touch upon the sensitive issues of ownership and control of domestic economic activities.

\section{Nationalism, patriotism, ethnocentrism, and consumer ethnocentrism}

Several related concepts, although conceptually different from economic nationalism, have been presented in international business and political science literature. These concepts include nationalism, patriotism, ethnocentrism, and consumer ethnocentrism. In the next section, we review these concepts and then present the expectations model of economic nationalism.

\section{Nationalism}

As citizens of a country, people live within a defined geopolitical area to which they become attached and with which they identify. Nations become personally relevant to individuals when they become sentimentally attached to their homeland, when they are motivated to help their country, and when they gain a sense of identity and selfesteem through national identification (Druckman, 1994). National identification and attachment produce evaluative judgments about one's own country and those of others. Kosterman and Feshbach (1989) equate nationalism with the perception of national superiority, an orientation toward national dominance, and a downward comparison of other nations. In their study in which they sampled different groups of Americans they found that the items that loaded on the nationalism factor appeared to imply an "America-first" or "American superiority" attitude. Terhune (1964) also notes that in the different definitions of nationalism, three features are present: national consciousness, national ethnocentrism, and national aspirations. Nationalists have a feeling of superiority for their country and also a belief that their country should be dominant (Kosterman and 
Feshbach, 1989). Nationalism thus shows an evaluative bias against other countries.

\section{Patriotism}

The issue of evaluative bias with respect to in-group and outgroup has also been explored in the literature on patriotism. Adorno et al. (1950) distinguish between healthy patriotism and ethnocentric patriotism. In healthy patriotism, love of one's country is not associated with prejudice against other countries. In ethnocentric patriotism, however, love of one's country is associated with such prejudices. What Adorno et al.(1950) define as ethnocentric patriotism closely resembles what Kosterman and Feshbach (1989) define as nationalism.

Kosterman and Feshbach (1989) make a conceptual distinction between nationalism and patriotism. Unlike nationalism, patriotism involves positive feelings towards one's own country, without the need for national power and dominance, two important characteristics of nationalism. Druckman (1994, pp. 47-8) also distinguishes between nationalism and patriotism by noting that patriotism is "commitment and readiness to sacrifice for the nation, while nationalism is commitment plus exclusion of others, a readiness to sacrifice bolstered by hostility toward others". In the two concepts, nationalism and patriotism, evaluative judgments are involved. However, patriotism, in contrast to nationalism, does not include a negative evaluative bias against other countries.

\section{Ethnocentrism}

Ethnocentrism refers to attitudinal dispositions toward people and objects that can be identified as in-groups or out-groups. Sumner (1906) introduced the concept of ethnocentrism and specified that it indicates favorable attitudes toward in-groups and unfavorable attitudes toward out-groups. Booth (1979) relates the concept of ethnocentrism with unfavorable images of people and symbols that are not part of one's reference group. Ethnocentric people thus view the symbols and values of their own groups as superior to the symbols and values of other groups (Levine and Campbell, 1972). Ethnocentrism, thus, is associated with nations, ethnic groups, symbols, and values. 
The dominant belief is that one's own nation, ethnic group, and values are superior to others.

\section{Consumer ethnocentrism}

Shimp and Sharma's (1987) concept of consumer ethnocentrism was adapted from the general concept of ethnocentrism. Their adaptation presented a consumer behavior perspective of ethnocentrism. They used the term consumer ethnocentrism to represent "the beliefs held by American consumers about the appropriateness, indeed morality, of purchasing foreign-made products" (Shimp and Sharma, 1987, p. 280). Their 17-item scale lists statements that can be categorized as belief oriented, prescriptive, or outcome oriented. Ethnocentric consumers are purported not to buy imported products because, among other things, it would hurt the domestic economy and because it will be seen as an unpatriotic act. Ethnocentric consumers will also recommend heavy taxes on imported products and a reduction in international trade. Consumer ethnocentrism, from a consumer behavior perspective, encompasses several dimensions. Sharma et al. (1995) note that the concept of consumer ethnocentrism is based on three tenets:

1. one's fear of economically harming one's beloved country by buying foreign products;

2. the morality of buying imported products; and

3. a personal prejudice against imports

\section{Expectations model of economic nationalism}

In contrast to the four concepts discussed above, economic nationalism is distinct. It seeks to safeguard domestic resources, industries, and people from the control of foreign firms, who are considered members of the out-group. Baughn and Yaprak (1996) note that economic nationalism is the adoption of an "us first" in the in-group versus out-group distinction relating to companies, products, jobs, and workers. This desire to keep economic activities under domestic control promotes expectations of others especially those who can play a role in curtailing the influence of foreign business in the domestic economy. These expectations are the result of the belief that domestic resources, industries, and jobs cannot be protected without 
the involvement of the domestic government and businesses and the general public. Economic nationalism is thus said to manifest itself in the "role that the national government, domestic firms, and general public is expected to play in curtailing the involvement of foreign firms in the domestic economy" (Akhter et al., 2003, p. 77). The concept of economic nationalism thus has a specific focus - preservation of the national economic autonomy. The emphasis is on protecting the domestic economy from the influence of foreign firms. This focus conceptually separates the concept of economic nationalism from other related concepts such as nationalism, patriotism, ethnocentrism, and consumer ethnocentrism.

In Figure 1 we show the expectations model of economic nationalism with its three dimensions - government, domestic firms, and general public. People's expectations are associated with these three groups because they can play a role in restricting the influence of foreign firms on the domestic economy. At the governmental level, for example, the discrimination against foreign firms can be carried out as a matter of policy (Macesich, 1985), which can take several forms such as the erection of tariff and nontariff barriers, nonobservance of international trade and copyright laws, rejection of foreign products, and provision of subsidies to domestic firms to improve their competitiveness (Reich, 1991; Johnson, 1967; Burnell, 1986). Governments can also oppose takeover bids of domestic firms. The French government, for example, opposed Switzerland's Novartis bid for Aventis, a French drug maker, on grounds of national interest (Carreyrou et al., 2004).

Domestic firms can also be expected to play a role in curtailing the involvement of foreign firms in the domestic economy. These actions, for example, can include blocking the sale of domestic firms to foreign firms or avoiding the formation of strategic alliances with foreign firms. Most Dutch companies, for example, have "poison pills" in their statutes that repel foreign takeovers (Carreyrou et al., 2004, p. A1). Domestic firms can also develop a network of relationships that exclude foreign firms and in which group members prefer to buy from one another. Such practices can set up barriers to entry for international firms.

In addition to the government and domestic firms, the public can also be expected to play a role in constraining the activities of Journal of Consumer Marketing, Vol 24, No. 9 (2007): pg. 142-150. DOI. This article is (c) Emerald and permission has been granted for this version to appear in e-Publications@Marquette. Emerald does not grant permission for this article to be further copied/distributed or hosted elsewhere without the express permission from Emerald. 
foreign firms. For example, the public can be expected to boycott foreign products or even to avoid working for foreign firms. These actions can curtail the involvement of foreign firms in the domestic economy. In Detroit, when US automobile manufacturers were losing market share to Japanese firms, people were expected to buy "domestic" to support domestic firms. In Japan, on the other hand, when news of importing US rice hit the newsstand, not only Japanese farmers, but also different sections of the general public objected to importing US rice.

\section{Measuring economic nationalism}

Although economic nationalism has been the subject of inquiry for a long time, the predominant focus of research in this area has been either descriptive or policy oriented. The exception, however, is the work of Baughn and Yaprak (1996). They provide a measure of economic nationalism, which is composed of 36 items, of which six items are from Shimp and Sharma's (1987) consumer ethnocentric scale, six from Yavas et al.'s (1980) study, and two from Sampson and Smith's (1957) study on immigrants' impact on domestic jobs. The authors also generated 22 of the 36 items specifically for their study. After scale refinement, Baughn and Yaprak (1996) retained 16 of the 36 items. The sixteen items cover issues related to prioritization, control, and effects, among others, of international trade and investments.

In our study, however, the premise is that economic nationalism, the desire to protect domestic economy from the influence of foreign firms, cannot be measured by asking people whether international trade or international investment is good or bad for the economy or whether immigrants should be allowed to work or not. This and other such measures, commonly used in the existing literature, reflect people's beliefs about international trade and investments, not their predisposition to economic nationalism.

The expectations model, in contrast, posits that at the individual level economic nationalism can be measured by examining expectations that people have of others, the government, domestic firms, and general public. These three groups can play a significant role in reducing the involvement of foreign firms in the domestic economy. As these three groups can reduce the involvement of foreign Journal of Consumer Marketing, Vol 24, No. 9 (2007): pg. 142-150. DOI. This article is (C) Emerald and permission has been granted for this version to appear in e-Publications@Marquette. Emerald does not grant permission for this article to be further copied/distributed or hosted elsewhere without the express permission from Emerald. 
firms in a domestic economy, what one expects of these three will be reflective of the degree of economic nationalism at the individual level. Higher levels of these expectations would be reflective of higher levels of economic nationalism.

\section{Method}

\section{Questionnaire}

To collect data, a survey questionnaire was developed and translated into Japanese from English following the recommended translation procedure for conducting cross-national research (Douglas and Craig, 1983). The questionnaire contained statements about people's expectations of what the government, domestic firms, and public should do with regard to managing foreign businesses. The statements are presented below in the "Items" sections. Subjects were asked to indicate their level of agreement or disagreement on a fivepoint Likert scale. The scale was anchored by strongly disagree and strongly agree.

\section{Sample}

The sampling frame consisted of students at a large university in Tokyo, Japan. The questionnaire was distributed to 134 students, all of whom responded to the survey. Although there are some concerns about using students as subjects, the use of students is considered appropriate for theory development and testing purposes (Calder et al., 1981). Recently, for example, many studies have used students as subjects to test measurement models. Durvasula et al. (1993) and Andrews et al. (1994) used student samples to examine the crossnational applicability of advertising attitude constructs. As this study focuses on using the psychological construct of "expectations" to determine the level of economic nationalism, the use of student subjects was considered appropriate. Furthermore, the use of students sample has the advantage of allowing findings from this study to be compared with those of other studies using students as subjects. 
NOT THE PUBLISHED VERSION; this is the author's final, peer-reviewed manuscript. The published version may be accessed by following the link in the citation at the bottom of the page.

\section{Items}

Expectations related to three groups (government, domestic firms, and the general public) were included in the questionnaire. The expectation statements were derived from studies that focus on actions of governments, domestic firms, and general public that can result in reducing the involvement of foreign firms in a country. The definition of the construct and the associated domain specifications also guided the selection of action-related expectation statements. Expectations with respect to the government included the following six items, which are that the Japanese government should:

1. set a limit on US investments in Japan;

2. not allow US firms to send profits back to the USA;

3. control US business involvements in all sectors of the Japanese economy;

4. have a restrictive set of rules for US businesses;

5. not buy US products; and

6. set an upper limit on market shares of US companies in Japan.

Expectations with respect to Japanese firms included the following four items, which are that Japanese firms should not:

1. sell their businesses to US firms;

2. form strategic alliances with US firms;

3. sell their technologies to US firms; and

4. buy American products if Japanese products are available.

Expectations with respect to general public included the following six items, which are that the Japanese public should:

1. boycott US products;

2. encourage others to boycott US products;

3. avoid working for US firms;

4. write letters to newspapers against US business practice; 
NOT THE PUBLISHED VERSION; this is the author's final, peer-reviewed manuscript. The published version may be accessed by following the link in the citation at the bottom of the page.

5. support politicians who want to reduce US business presence in Japan; and

6. encourage public officials to take actions against American firms.

\section{Statistical procedure}

A confirmatory factor analysis was conducted, using the LISREL 8.5 statistical package (Joreskog and Soresbom, 1996). Factor analysis shows the pattern of relationships among the variables and the constructs. The fit between the model implied covariance matrix and sample covariance matrix is judged by different statistical tests of the goodness-of-fit. Confirmatory factor analysis was conducted because it is considered appropriate for scale validation in measuring specific constructs (Steenkamp and van Trijp, 1991).

\section{Findings}

LISREL output provides several measures of goodness-of-fit. The $X^{2}$ value of 240.27 with 101 degrees of freedom shows a ratio of 2.37. A $X^{2}$ ratio of 3 or 2 or less has been advocated as an acceptable level of fit for confirmatory factor model (Carmines and McIver, 1981). As the Chi-square test is an omnibus test, it is recommended that this measure be supplemented with other goodness-of-fit measures to judge the fit between the model-implied covariance matrix and the sample covariance matrix. The goodness-of-fit index was 0.81 , which shows an acceptable fit. The adjusted goodness-of-fit index of 0.75 shows a marginal fit. The root mean square residual, which is an average of the residuals between the observed and estimated input matrices, was 0.093. The composite reliability measures, which are similar to Cronbach's coefficient alpha, were also calculated for the three dimensions of economic nationalism. For government the reliability was 0.70 , for public 0.85 , and for firms 0.69 . These reliability measures are close to the recommended level of 0.70 (Hair et al., 1998). Overall, the proposed model shows an acceptable fit (see Table I). 
NOT THE PUBLISHED VERSION; this is the author's final, peer-reviewed manuscript. The published version may be accessed by following the link in the citation at the bottom of the page.

\section{Nomological validity}

Given that the proposed model shows an acceptable fit, the nomological validity of the model needs to be established. Nomological validity is established by showing that the model specified constructs are related to other constructs not included in the model in a way that is theoretically supported (Hair et al., 2006). As indicated earlier, the expectations model is based on the premise that the level of economic nationalism can be determined by examining what one expects others to do with regard to reducing the involvement of foreign firms in the domestic economy. If someone expects the government, domestic firms, and the general public to act in ways that restrict the involvement of foreign firms, then he or she would also be more likely to engage in behaviors that achieve the same goal. Thus, a significant conceptual link between one's expectations of others and one's own intentions to behave in specific ways that would reduce the involvement of foreign firms in the domestic economy would help establish nomological validity.

The nomological validity of the model was established by following the recommended procedure (Hair et al., 2006). The twostep procedure requires the calculation of factor scores and correlating these factor scores with related variables. For this study, the factor score for each dimension was calculated and then correlated with the following four items: respondent's intention not to buy US product, intention to recommend friends to buy only Japanese products, intention to buy US products only if Japanese products are not available, and intention to discourage friends from buying US products. The expectation model would predict positive and significant correlation with each of these intentions. Correlations between factor scores and the four intention items were calculated. All correlations were positive and significant at less than the 0.05 level (Table II). These positive and significant correlations support the nomological validity of the proposed economic nationalism model.

\section{Conclusions and implications}

Although the significance of economic nationalism is recognized in the literature, neither the conceptual domain nor the empirical indicators for measuring the concept has been discussed adequately. 
There is, in particular, a paucity of studies focusing on the empirical measurement of economic nationalism. Furthermore, existing research has not differentiated economic nationalism from conceptually related, but distinct, concepts such as ethnocentrism, consumer ethnocentrism, nationalism, and patriotism. This has had two inevitable consequences. First, it has made it difficult to show generalizable relations with regard to the antecedents and consequences of economic nationalism. Second, scholarly attempts to purify the concept have suffered because of the absence of a rigorous empirical treatment of the concept.

This study attempts to add to the literature by building on the existing literature and proposing the expectations model of economic nationalism. The expectations model is based on the premise that individuals acting alone cannot protect the domestic economy from the influence of foreign firms. The activities of these firms are varied and they have both financial and political resources to achieve their goals in a host country. People recognize the power that these corporations command and exert. Therefore, they will expect others, those who control resources and enjoy decision making power, to take actions that would result in reducing the influence of foreign firms over domestic economy.

The model suggests that economic nationalism can be measured by expectations that individuals have of others, especially the government, domestic firms, and the general public in restricting the activities of foreign firms. Based on this model, individuals holding high expectations of these groups will be considered more economically nationalistic. Thus, it is being argued that the more these individuals expect the government, domestic firms, and the general public to play a role in controlling foreign businesses, the more economically nationalistic they themselves will be.

Strategically, as the global economy becomes more integrated, disruptions caused by economic nationalism can have deleterious consequences. Although the business environment has improved with the opening of economies and increasing transparency, economic nationalism continues to shape the business environment in every country market. For multinationals, these disruptions can impede the achievement of financial and marketing goals. A proactive approach for multinationals would involve not only emphasizing the benefits they Journal of Consumer Marketing, Vol 24, No. 9 (2007): pg. 142-150. DOI. This article is (c) Emerald and permission has been granted for this version to appear in e-Publications@Marquette. Emerald does not grant permission for this article to be further copied/distributed or hosted elsewhere without the express permission from Emerald. 
will derive from entering a country market, but also the benefits they will deliver to the domestic economy by entering the country market.

The proposed expectations model of economic nationalism is supported by confirmatory factor analysis. Nomological validity further establishes the validity of the proposed model. Given that this research is country based, future studies can test the genaralizability of the model with cross-national data. A second stream of research can focus on examining the difference in the degree of economic nationalism with respect to different countries. That is, are Japanese more economically nationalistic toward the USA than, say, China.

\section{References}

Adorno, T.W., Frankel-Brunswick, D.J., Levinson, N.R., Sanford, B.A., Levinson, M.H. and Morrow, W. (1950), The Authoritarian Personality, Harper Row, New York, NY.

Agiomirgiankis, G. and Zervoyinanni, A. (2001), "Globalization of labor markets and macroeconomic equilibrium", International Review of Economics and Finance, Vol. 10 No. 2, pp. 109-33.

Akhter, S.H., Kim, D.S. and Hosseini, J. (2003), "The influence of economic nationalism and product quality on behavioral intentions: an empirical investigation", Journal of Global Business, Spring, pp. 75-83.

Andrews, J.C., Durvasula, S. and Netemeyer, R.D. (1994), "Testing the crossnational applicability of US and Russian advertising belief and attitude measures", Journal of Advertising, Vol. 21 No. 7, pp. 71-82.

Baughn, C.C. and Yaprak, A. (1996), "Economic nationalism: conceptual and empirical development", Political Psychology, Vol. 17 No. 4, pp. 75978.

Booth, K. (1979), Strategy and Ethnocentrism, Croom-Helm, London.

Burnell, P.J. (1986), Economic Nationalism in the Third World, Harvester Press, Brighton.

Calder, B., Phillips, L.W. and Tybout, A. (1981), "Designing research for application", Journal of Consumer Research, Vol. 8, September, pp. 197-207.

Carmines, E. and McIver, J. (1981), "Analyzing models with unobservable variables: analysis of covariance structures", in Bohrnstedt,G.and Borgotta,E.(Eds), Social Measurement: Current Issues, Sage

Publications, Beverly Hills, CA, pp. 65-115.

Journal of Consumer Marketing, Vol 24, No. 9 (2007): pg. 142-150. DOI. This article is (c) Emerald and permission has been granted for this version to appear in e-Publications@Marquette. Emerald does not grant permission for this article to be further copied/distributed or hosted elsewhere without the express permission from Emerald. 
NOT THE PUBLISHED VERSION; this is the author's final, peer-reviewed manuscript. The published version may be accessed by following the link in the citation at the bottom of the page.

Carreyrou, J., Raghavan, A. and Naik, G. (2004), "Native industry: in face of French resistance, Swiss giant enters takeover fray", The Wall Street Journal, April 23, p. A1 and A10.

Douglas, S. and Craig, C.S. (1983), International Marketing Research, Prentice-Hall, Englewood Cliffs, NJ.

Druckman, D. (1994), "Nationalism, patriotism, and group loyalty: a social psychological perspective", Mershon International Studies Review, Vol. 38 No. 1, pp. 43-68.

Durvasula, S., Andrews, J.C., Lysonski, S. and Netemeyer, R.G. (1993), "Assessing the cross-national applicability of consumer behavior models: a model of attitude toward advertising in general", Journal of Consumer Research, Vol. 19, March, pp. 626-36.

(The) Economist (2000), "The Americas: the nationalist groundswell in Brazil", February 26, p. 45.

Greider, W. (1997), One World, Ready or Not - The Manic Logic of Global Capitalism, Simon \& Schuster, New York, NY.

Hair, J.F. Jr, Anderson, R.E., Tatham, R.L. and Black, W.C. (1998), Multivariate Data Analysis, 5th ed., Prentice-Hall, Englewood Cliffs, NJ.

Hair, J.F. Jr, Black, W., Babin, B., Anderson, R. and Tatham, R.L. (2006), Multivariate Data Analysis, 6th ed., Prentice-Hall, Englewood Cliffs, NJ.

Han, C.M. (1988), "The effects of cue familiarity on cue utilization: the case of country of origin", paper presented at the Conference of the Academy of International Business, San Diego, CA.

Hoon, S.J. and Lee, C.S. (1998), "Unlocking the citadel", Far Eastern Economic Review, March 26, pp. 10-12.

Johnson, H.G. (1967), "A theoretical model of economic nationalism in new and developing states", in Johnson, H. (Ed.), Economic Nationalism in Old and New States, University of Chicago Press, Chicago, IL.

Joreskog, K. and Soresbom, D. (1996), LISREL 8: User's Reference Guide, SSI Scientific Software International, Chicago, IL.

Knox, P. (1997), "Globalization and urban economic change", The Annals of the American Academy of Political and Social Science, No. 551, May, pp. 17-27.

Kosterman, R. and Feshbach, S. (1989), "Toward a measure of patriotic and nationalistic attitudes", Political Psychology, Vol. 10 No. 2, pp. 257-74. 
NOT THE PUBLISHED VERSION; this is the author's final, peer-reviewed manuscript. The published version may be accessed by following the link in the citation at the bottom of the page.

Lander, M. and Meller, P. (2006), "Unity in the European market, except when it comes to takeovers", New York Times, March 14

Lee, C.S. (1998), "Financial leverage", Far Eastern Economic Review, April 9, p. 45.

Levine, R. and Campbell, D.T. (1972), Ethnocentrism: Theories of Conflict, Ethnic Attitudes, and Group Behavior, John Wiley \& Sons, New York, NY.

Macesich, G. (1985), Economic Nationalism and Stability, Prager, New York, NY.

Mele, C. (1996), "Globalization, culture, and neighborhood change: reinventing the lower east side of New York", Urban Affairs Review, Vol. 32 No. 1, pp. 3-22.

Miller, A. (1990), "What is managed trade and will it work", Newsweek, March 5, p. 26.

Power and Interest News Report (2006), March 3, available at: www.pinr.com/report

Reich, R.B. (1991), The Work of Nations: Preparing Ourselves for 21st Century Capitalism, Knopf, New York, NY.

Sampson, D.L. and Smith, H.P. (1957), "A scale to measure world-minded attitudes", The Journal of Social Psychology, Vol. 45, February, pp. 99106.

Segal-Horn, S. (2002), "Global firms - heroes or villains? How and why companies globalize", European Business Journal, Vol. 14 No. 1, pp. 819.

Sharma, S., Shimp, T.A. and Shin, J. (1995), "Consumer ethnocentrism: a test of antecedents and moderators", Journal of the Academy of Marketing Sciences, Vol. 23 No. 1, pp. 26-37.

Shimp, T. and Sharma, S. (1987), "Consumer ethnocentrism: construction and validation of the CETSCALE", Journal of Marketing Research, Vol. 24 No. 3, pp. 280-9.

Slater, J. (1998), "What's in a name", Far Eastern Economic Review, March 26, pp. 14-15.

Steenkamp, J.E.M. and van Trijp, H.C.M. (1991), "The use of LISREL in validating marketing constructs", International Journal of Research in Marketing, Vol. 8 No. 4, pp. 283-99.

Journal of Consumer Marketing, Vol 24, No. 9 (2007): pg. 142-150. DOI. This article is (c) Emerald and permission has been granted for this version to appear in e-Publications@Marquette. Emerald does not grant permission for this article to be further copied/distributed or hosted elsewhere without the express permission from Emerald. 
NOT THE PUBLISHED VERSION; this is the author's final, peer-reviewed manuscript. The published version may be accessed by following the link in the citation at the bottom of the page.

Sumner, W.G. (1906), Folkways: The Sociological Importance of Usages, Manners, Customs, Mores, and Morals, Ginn \& Co., New York, NY.

Terhune, K.W. (1964), "Nationalism among foreign and American students: an exploratory study", Conflict Resolution, Vol. 8 No. 3, pp. 256-70.

Weisman, J. (2004), "Bush, advisor assailed for stance on 'offshoring' jobs", The Washington Post, February 11, p. A06.

Westervelt, R. (2002), "OMG, Bayer and Cabot cited for exploitation in Africa", Chemical Week, October 30, p. 12.

World Peace Herald (2006), March 3, available at: www.wpherald.com/report.php

Yavas, U., Yaprak, A. and Riecken, R. (1980), "Worldmindedness, issuespecific and socioeconomic correlates of perceptions of foreign-based companies: some cross-cultural insights", paper presented at the National Meeting of the Academy of International Business, New Orleans, LA.

\section{About the author}

Syed H. Akhter is Chairman of the Marketing Department at Marquette University. His research interests include foreign market entry strategies, globalization, e-commerce, and consumer psychology. He has published extensively in international business and marketing journals such as Journal of International Business Studies, International Marketing Review, European Journal of Marketing, International Trade Journal, Business Horizons, and Journal of Advertising. He has published two books, Global Marketing and Strategic Marketing and guest edited special issues of the Journal of Direct Marketing on International Direct Marketing and a special issue of the Journal of Interactive Marketing on International Interactive Marketing. Dr. Akhter serves as a consultant and conducts global marketing and strategic planning seminars internationally. Syed $\mathrm{H}$. Akhter can be contacted at:

syed.akhter@marquette.edu

\section{Executive summary and implications for managers and executives}

This summary has been provided to allow managers and executives a rapid appreciation of the content of this article in toto to take advantage of the more comprehensive description of the research undertaken and its results to get the full benefit of the material present. 
NOT THE PUBLISHED VERSION; this is the author's final, peer-reviewed manuscript. The published version may be accessed by following the link in the citation at the bottom of the page.

\section{Why anti-globalization is increasing}

Not everyone warmly embraces globalization. Opposition is growing and many analysts believe this will result in greater demands for tighter control of global trade and investment. That globalization means that the health of economies is even more dependent on market forces prompts critics to hold it responsible when jobs are lost or wages slashed. Others believe it also threatens social unity while further deepening inequalities throughout the world.

Anti-globalization sentiments are evident in more advanced economies as well as in nations regarded as less developed. For instance, the arrival of McDonald's and Kentucky Fried Chicken in India prompted a clamor that domestic business should enjoy greater protection. Similar concerns even surfaced in the USA to the extent that the impact of outsourcing on the American workforce became a high profile issue during the 2004 presidential election campaign.

Akhter claims that such worries have led to the growth of what he terms "economic nationalism" as a means of putting the brakes on globalization's incessant march. Its emergence is driven by the desire to put the host nation's companies, goods, jobs and people before those of foreign competitors. It can lead to actions such as the boycotting of foreign products, a refusal to sell businesses to foreign firms and government erection of international trade and investment barriers. The impact can seriously damage the marketing and business activities of multinational organizations that need easy access to foreign markets and resources in order to thrive.

The motivation for economic nationalism can be:

- Political. People are aware of instances where foreign companies have played a major role when questionable activities have been carried out within host countries. One example cited is The East India Company of Britain's involvement when India became a colony of the British Empire. A more recent example surfaced when the UN accused several firms of exploiting natural resources in the Democratic Republic of Congo.

- Economic. This stems from the belief that domestic business needs safeguarding against the threat posed by well resourced and market savvy foreign rivals. Supporters fear that losing control of domestic business makes for an uncertain future not least because of the inevitable resulting vulnerability of some domestic firms. 
NOT THE PUBLISHED VERSION; this is the author's final, peer-reviewed manuscript. The published version may be accessed by following the link in the citation at the bottom of the page.

- National security. In this respect, worry arises through suspicion that foreign companies may not be committed to achieving domestic goals. There is also the fear of the unknown factor and this can trigger dramatic responses. In France, for example, the government has introduced legislation banning foreign takeovers in several key industries.

\section{A conceptual framework for economic nationalism}

Although economic nationalism has been around for some time, interpretations differ and it is often confused with the similar yet distinct concepts of nationalism, patriotism, ethnocentrism and consumer ethnocentrism. Nationalism has been defined as emerging through a sense of national identification that inspires exponents to believe in superiority over other nations. A key tenet is that the nation should dominate these perceived inferiors. While patriotism is similarly based on national pride and positive feelings towards one's country, it comes packaged without the desire to dominate or express hostility towards other countries. Ethnocentrism's foundations center on the division between those who belong in a certain group and those who do not. Similarly to nationalism, this generates warm feelings to group members while perceived outsiders are regarded in a less positive light. With consumer ethnocentrism, the reference is specifically to foreign goods. Believers question the morality of those who purchase such goods and consider it an unpatriotic act that has the potential to harm the domestic economy. They will often demand substantial levies on imported goods and a reduction in overall international trade.

Akhter aims to build on existing research by proposing and testing a model for measuring economic nationalism. He points out that previous studies in the area have not paid attention to measuring the concept and that general assumption has been that it simply relates to whether people view international trade in a positive or negative light. The author argues that this merely measures belief, which does not necessarily indicate a penchant for economic nationalism.

Instead, he proposes his "expectations model" as a more accurate way of measuring economic nationalism. He points out that the model's relevance stems from the fact that it focuses on the expectations people have of those better positioned to take action that will help safeguard national interests:

- Government. Can introduce policies that restrict the activities of foreign organizations. Such action can manifest itself in the rejection of foreign goods, subsidies to make domestic firms more competitive, different tariff quotas and noncompliance with international trade agreements. 
NOT THE PUBLISHED VERSION; this is the author's final, peer-reviewed manuscript. The published version may be accessed by following the link in the citation at the bottom of the page.

- Domestic companies. Can refuse to enter alliances with foreign firms, block sales to such organizations and form networks with other domestic companies that exclude foreign involvement and confine activities to those within the network.

- The general public. Can shun foreign products and refuse to work for international companies. When faced with a threat from foreign companies, the public often responds by demanding that consumers buy only domestically-made products.

The model was tested by distributing a questionnaire to 134 students in Tokyo, Japan. Participants were asked about their expectations of what the government, domestic firms and the public should do with regard to controlling the influence of foreign business in the country. They were presented with a series of statements relating to suggested actions that government, domestic companies and the public should take and were asked to indicate how strongly they agreed or disagreed. Akhter claims that higher expectation levels indicate a greater tendency towards economic nationalism.

Different measures were used to analyze results and demonstrate the model's validity. The author found a significant conceptual link between respondents' expectations of others and the expression of their own behavioral intentions, which were measured by responses to questions about their attitude and how they would try to influence friends' attitude towards the purchase of domestic and foreign goods respectively.

The expectations model is based on the premise that individuals acting alone can do little to halt the activities of foreign organizations that possess enough financial and political clout needed to fulfill their business objectives within a host country. Individuals thus rely on others better empowered to make the decisions that will help protect national interests. The author believes that expecting these others to take necessary action is a valid measure of economic nationalism.

\section{Implications and further research}

Economic nationalism has the potential to impede the achievement of business and financial goals. Akhter suggests that the best strategy multinational organizations can adopt is to highlight the benefits their activities can bring to a host nation instead of justifying their presence with reference to the rewards they hope to enjoy themselves.

Further investigation is needed before any generalizations can be drawn. The author suggests that the model could be tested across a whole nation and that additional research conducted in different countries would help identify 
NOT THE PUBLISHED VERSION; this is the author's final, peer-reviewed manuscript. The published version may be accessed by following the link in the citation at the bottom of the page.

countries where economic nationalism is most prevalent and those where the sentiment is not as strong.

(A précis of the article "Globalization, expectations model of economic nationalism, and consumer behavior". Supplied by Marketing Consultants for Emerald.)

\section{Appendix}

Figure 1: Dimensions of economic nationalism

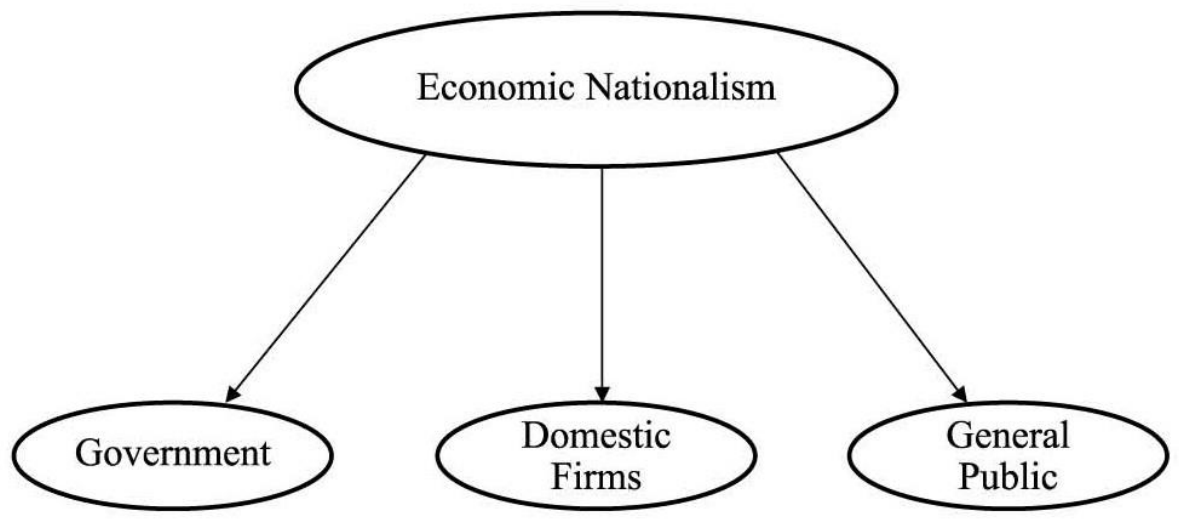

Table I: Goodness-of-fit measures for the estimated model

\begin{tabular}{lc}
\hline Goodness-of-fit measures & Estimated model \\
\hline Absolute fit measures & \\
Chi-square $\left(X^{2}\right)$ & 240.27 \\
Degrees of freedom & 101 \\
Goodness of fit index & 0.81 \\
Roots mean square residual & 0.093 \\
Incremental fit measures & \\
Adjusted goodness-of-fit index & 0.75 \\
Normed fit index & 0.70 \\
Reliabilities & \\
Government & 0.70 \\
Public & 0.85 \\
Firm & 0.69 \\
\hline
\end{tabular}


NOT THE PUBLISHED VERSION; this is the author's final, peer-reviewed manuscript. The published version may be accessed by following the link in the citation at the bottom of the page.

Table II: Correlation matrix

\begin{tabular}{|c|c|c|c|c|c|c|c|}
\hline & $\begin{array}{l}\text { Not buy } \\
\text { product }\end{array}$ & $\begin{array}{l}\text { Persuade } \\
\text { friends }\end{array}$ & $\begin{array}{l}\text { Buy if Japanese } \\
\text { product not available }\end{array}$ & $\begin{array}{l}\text { Discourage } \\
\text { friends }\end{array}$ & Government & Public & Firms \\
\hline Not buy product & 1 & & & & & & \\
\hline Persuade friends & $0.545^{\star \star}$ & 1 & & & & & \\
\hline $\begin{array}{l}\text { Buy if Japanese product not } \\
\text { available }\end{array}$ & $0.307^{\star *}$ & $0.353^{\star \star}$ * & 1 & & & & \\
\hline Discourage friends & $0.526^{* *}$ & $0.660^{* *}$ & $0.387^{\star \star} \star$ & 1 & & & \\
\hline Government & $0.346^{\star *}$ * & $0.394^{*}$ * & $0.234^{*}$ * & $0.345^{\star *}$ & 1 & & \\
\hline Public & $0.524^{\star \star}$ & $0.606^{\star \star} \star$ & $0.174^{\star}$ & $0.499^{\star \star} \star$ & $0.475^{\star \star}$ & 1 & \\
\hline Firms & $0.353^{* *}$ & $0.417^{\star *}$ & $0.208^{\star}$ & $0.321^{* *}$ & $0.327^{* *}$ & $0.573^{\star *}$ & 1 \\
\hline
\end{tabular}

Journal of Consumer Marketing, Vol 24, No. 9 (2007): pg. 142-150. DOI. This article is (c) Emerald and permission has been granted for this version to appear in e-Publications@Marquette. Emerald does not grant permission for this article to be further copied/distributed or hosted elsewhere without the express permission from Emerald. 